\title{
Pemberian Diet Formula Tepung Ikan Gabus (Ophiocephalus striatus) pada Sindrom Nefrotik
}

\author{
Trully Kusumawardhani, M. Mexitalia, JC. Susanto, Lydia Kosnadi
}

Latar belakang. Pemberian diet dengan protein seimbang pada sindrom nefrotik bertujuan untuk meningkatkan kadar albumin serum. Ikan gabus merupakan ikan air tawar yang banyak dijumpai di Indonesia dan memiliki kadar protein lebih tinggi dibandingkan ikan lainnya.

Tujuan Penelitian. Penelitian ini bertujuan untuk mengevaluasi pemberian suplementasi formula tepung ikan gabus terhadap peningkatan kadar albumin serum pasien sindrom nefrotik.

Metodologi. Penelitian uji klinik terbuka dilakukan di Bangsal Anak RS Dr. Kariadi Semarang, pada 36 anak dengan sindrom nefrotik kelainan minimal, yang terbagi dalam kelompok perlakuan dan kelompok kontrol. Kelompok perlakuan mendapatkan suplementasi ikan gabus, dengan cara mengganti $25 \%$ kebutuhan protein dengan tepung ikan gabus. Suplemntasi ikan gabus diberikan setiap hari selama 21 hari, dengan jumlah protein total yang diberikan sama dengan kelompok kontrol. Indeks masa tubuh (IMT), protein total, albumin dan globulin serum diukur setiap minggu, sedangkan akseptabilitas tepung ikan gabus dinilai setiap hari. Analisis statistik menggunakan uji t independent. Hasil. Pada kedua kelompok didapatkan peningkatan IMT, kadar protein total dan albumin serum pada akhir penelitian dibandingkan dengan data awal. Tidak didapatkan perbedaan kadar protein total dan globulin pada akhir penelitian antara kelompok perlakuan dan kelompok kontrol. Selisih kenaikan kadar albumin pada kelompok perlakuan $(2,04 \pm 1,47 \mathrm{~g} / \mathrm{dl})$ lebih tinggi secara bermakna dibandingkan dengan kelompok perlakuan $(1,47 \pm 0,82 \mathrm{~g} / \mathrm{dl})$ dengan nilai $\mathrm{p}=0,018$.

Kesimpulan. Pemberian suplementasi tepung ikan gabus selama 21 hari pada pasien sindrom nefrotik kelainan minimal dapat meningkatkan kadar albumin serum.

Kata kunci: tepung ikan gabus, albumin, sindrom nefrotik.

\footnotetext{
Alamat korespondensi: Dr. M. Mexitalia, Sp.A(K)

Bagian Ilmu Kesehatan Anak Fakultas Kedokteran Universitas Diponegoro / RS Dr. Kariadi. Jl. Dr. Sutomo 16 Semarang.

Telepon/Fax. 0218414296

E-mail : maria_mexitalia@yahoo.com
}

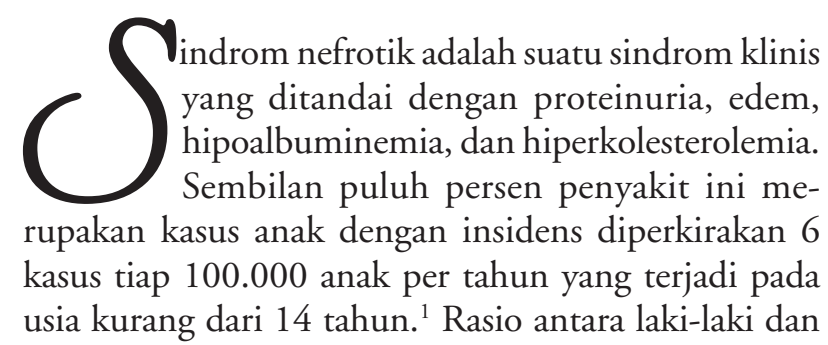


perempuan 2:1. ${ }^{1,2}$ Pengobatan yang diberikan meliputi pengobatan medikamentosa dengan menggunakan preparat kortikosteroid dan pengobatan suportif yaitu pengelolaan dietetik, terutama masukan protein. ${ }^{1}$ Dahulu dianjurkan pemberian diet tinggi protein untuk mengimbangi terjadinya proteinuria. Tetapi beberapa penelitian menunjukkan bahwa hal tersebut dapat membahayakan fungsi ginjal karena akan meningkatkan proteinuria, menyebabkan hiperfiltrasi glomerular sehingga menyebabkan gangguan fungsi ginjal, sementara kadar albumin serum tidak meningkat. ${ }^{3,4}$ Sebaliknya, pemberian diet rendah protein juga tidak dianjurkan karena akan menyebabkan keseimbangan nitrogen negatif dan malnutrisi protein walaupun dapat menurunkan kejadian proteinuria. ${ }^{1,3}$ Penelitian terkini menganjurkan pemberian diet dengan kadar protein seimbang sesuai dengan kebutuhan dan dengan memperhatikan fungsi ginjal yang masih normal, dilihat dari kadar ureum dan kreatinin yang masih berada pada rentang normal. ${ }^{4-5}$

Sumber protein makanan dapat berasal dari hewani maupun nabati. Protein hewani dinilai memiliki nilai biologis yang lebih tinggi dibandingkan dengan protein nabati, karena protein hewani memiliki komposisi asam amino esensial yang sama dengan protein tubuh manusia. ${ }^{6-7}$ Salah satu sumber protein hewani yang cukup baik adalah ikan. Salah satu jenis ikan air tawar di Indonesia yang kita kenal adalah ikan gabus (Ophiocephalus striatus) yang mempunyai potensi tinggi karena mengandung kadar protein yang tinggi, bahkan lebih tinggi daripada ikan lainnya. ${ }^{8}$ Soemarko, ${ }^{9} 2002$ melakukan penelitian pemberian nutrisi enteral dengan ekstrak albumin dari ikan gabus selama 16 hari pada pasien hipoalbuminemia dengan fistula enterokutan, didapatkan peningkatan bermakna kadar albumin serum sebelum dan sesudah perlakuan.

Tujuan dari penelitian ini untuk mengetahui pengaruh pemberian suplementasi formula tepung ikan gabus dalam meningkatkan kadar albumin serum pada pasien sindrom nefrotik.

\section{Metodologi}

Penelitian ini merupakan uji klinik terbuka dengan pengukuran sebelum dan sesudah perlakuan. Penelitian dilakukan di Bangsal Kesehatan Anak RS Dr. Kariadi
Semarang, sejak bulan Juni 2002 sampai Mei 2004. Kriteria inklusi adalah anak berusia 2 sampai 14 tahun yang menderita sindrom nefrotik kelainan minimal berdasarkan perhitungan formula Y (ISKDC 1978) dengan nilai $>0,85,{ }^{10}$ dan dapat menerima diet secara oral. Kriteria eksklusi apabila mendapat transfusi plasma/abumin, meninggal dunia selama pengamatan, dan akseptabilitas terhadap formula ikan gabus buruk atau mendapatkan diet tepung ikan gabus kurang dari 21 hari. Kelompok kontrol diambil dari penderita yang dirawat sebelumnya (data dari catatan medis) yang disebut sebagai historical control, yang memiliki karakteristik yang sama dengan kelompok perlakuan (sesuai kriteria Pacock). ${ }^{11}$ Besar sampel penelitian dihitung berdasarkan uji hipotesis terhadap rerata dua populasi dan didapatkan minimal jumlah subyek 16 pada tiap kelompok. ${ }^{12}$

Kelompok perlakuan mendapatkan diet tepung ikan gabus yang dibuat oleh Puslitbang Gizi Depkes RI di Bogor. Diet yang diberikan berupa diet standar dengan protein dimulai dari $1,5 \mathrm{~g} / \mathrm{kg} \mathrm{BB} / \mathrm{hari}$. Dua puluh lima persen dari total kebutuhan protein diganti dengan tepung ikan gabus, dengan rumus $(0,25 \times \mathrm{BB} \times$ kebutuhan protein)/0,16, karena tiap 100 gram tepung ikan gabus mengandung 16 gram protein. ${ }^{13}$ Tepung diolah oleh Bagian Gizi RS Dr. Kariadi menjadi 3 variasi lauk, dan diberikan selama 21 hari. Akseptabilitas dipantau oleh petugas gizi dan dicatat berapa banyak sisa atau tepung yang tidak dimakan. Data akseptabilitas diukur berdasarkan sisa lauk tepung ikan sesudah makan, dan dinyatakan akseptabilitas baik bila sisa lauk tepung ikan tidak lebih dari 50\%. Data awal sebelum diberikan perlakuan diperiksa pada hari perawatan ke-7 $(\mathrm{H}+7)$, meliputi pemeriksaan berat badan dan tinggi badan, kemudian dihitung indeks masa tubuh (IMT). Pemeriksaan laboratorium terdiri dari pemeriksaan darah meliputi protein total, albumin, globulin, kolesterol, ureum, kreatinin, serta pemeriksaan proteinuria. Pemeriksaan antropometri dan laboratorium (protein total, albumin, globulin, kolesterol dan proteinuria) dilakukan setiap minggu sampai 21 hari setelah perlakuan $(\mathrm{H}+28)$. Kelompok kontrol diambil berdasarkan catatan medik yang mempunyai karakterisktik penyakit dan pemeriksaan yang sama dan hanya mendapatkan diet standar untuk sindrom nefrotik. Analisis statistik dilakukan dengan menggunakan uji $\mathrm{t}$ independent, dan nilai $\mathrm{p}<0,05$ dinyatakan bermakna secara statistik. 
Sari Pediatri, Vol. 8, No. 3, Desember 2006

\section{Hasil Penelitian}

Selama 2 tahun periode penelitian yaitu sejak bulan Mei 2002 sampai Juni 2004, telah dirawat 21 orang penderita sindrom nefrotik. Selama perawatan, 1 anak mendapatkan transfusi fresh frozen plasma (FFP) dan 2 anak dirawat kurang dari 28 hari, sehingga jumlah subyek yang menyelesaikan penelitian adalah 18 anak. Dari data catatan medis didapatkan 35 penderita sindrom nefrotik yang dirawat antara Januari 1999 sampai Desember 2002. Dilakukan pemilihan sesuai dengan kriteria inklusi dan didapatkan 18 anak dengan sindrom nefrotik sebagai kontrol, sehingga jumlah total subyek penelitian adalah 36 anak. Sebagian besar subyek (15 dari 18 anak) dapat menghabiskan tepung ikan yang diberikan, sedangkan pada 3 anak tepung ikan masih tersisa kurang dari 25\%. Dengan demikian akseptabilitas anak terhadap tepung ikan gabus disimpulkan baik.
Rerata umur pada kelompok perlakuan (71,5 bulan) lebih muda dibandingkan dengan kelompok kontrol (94,9 bulan), demikian pula rerata IMT pada kelompok perlakuan $\left(13,9 \mathrm{~kg} / \mathrm{m}^{2}\right)$ lebih kecil dibandingkan dengan kelompok kontrol $\left(14,7 \mathrm{~kg} / \mathrm{m}^{2}\right)$, namun secara statistik perbedaan tersebut tidak bermakna (Tabel 1). Tidak didapatkan perbedaan pada data awal laboratorium, kecuali pada kadar albumin kelompok kontrol yang lebih tinggi $(1,75 \pm 0,59 \mathrm{~g} /$ dl) dibandingkan kelompok perlakuan ( $1,39 \pm 0,30$ $\mathrm{g} / \mathrm{dl}$ ). Karena kondisi tersebut maka dilakukan perhitungan dengan melihat perubahan (selisih D) kadar albumin pada pengamatan minggu berikutnya.

Tabel 2 dan 3 memperlihatkan perbedaan IMT, kadar protein dan albumin pada akhir penelitian dibandingkan awal penelitian pada kelompok perlakuan. Didapatkan peningkatan bermakna IMT, kadar protein total dan albumin. Peningkatan IMT,

Tabel 1. Karakteristik awal subyek penelitian

\begin{tabular}{lcc}
\hline Variabel & $\begin{array}{c}\text { Kelompok } \\
\text { Perlakuan } \\
\mathbf{n = 1 8}\end{array}$ & $\begin{array}{c}\text { Kelompok } \\
\text { Kontrol } \\
\mathbf{n}=\mathbf{1 8}\end{array}$ \\
\hline $\begin{array}{l}\text { Umur (bulan); rerata(SD) } \\
\text { Jenis kelamin }\end{array} \quad 71,5(37,4)$ & $94,9(29,4)$ \\
$\quad$ Laki-laki $\quad$ Perempuan & 4 & 3 \\
Jenis kasus & 14 & 15 \\
$\quad$ Kasus baru & 10 & 10 \\
$\quad$ Relaps & 8 & 8 \\
IMT (kg/m²); rerata(SD) & $13,9(1,6)$ & $14,8(2,1)$ \\
Laboratorium: & & \\
Kadar protein serum total (mg/dl); rerata (SD) & $3,82(0,52)$ & $4,12(0,82)$ \\
Kadar albumin serum total (mg/dl); rerata (SD) & $1,39(0,30)$ & $1,75(0,59)$ \\
Kadar globulin serum total (mg/dl); rerata (SD) & $2,44(0,51)$ & $2,37(0,69)$ \\
Kadar kolesterol serum (mg/dl); rerata (SD) & $479,1(175,1)$ & $464,3(166,0)$ \\
Kadar ureum darah (mg/dl); rerata (SD) & $27,6(14,9)$ & $29,6(18,1)$ \\
Kadar kreatinin darah (mg/dl); rerata (SD) & $0,51(0,22)$ & $0,57(0,17)$ \\
Kadar proteinuria (g/dl); rerata (SD) & $456,9(126,0)$ & $398,6(169,0)$ \\
\hline
\end{tabular}

Tabel 2. Rerata variabel pada awal dan akhir penelitian.

\begin{tabular}{lcccccc}
\hline Variabel & $\begin{array}{c}\text { Perlakuan } \\
\text { Awal } \\
(\text { minggu I) }\end{array}$ & $\begin{array}{c}\text { Akhir } \\
(\text { minggu IV) }\end{array}$ & $\mathbf{p}$ & $\begin{array}{c}\text { Awal } \\
(\text { minggu I) }\end{array}$ & $\begin{array}{c}\text { Perlakuan } \\
\text { Akhir } \\
(\text { minggu IV) }\end{array}$ & p \\
\hline IMT $\left(\mathrm{kg} / \mathrm{m}^{2}\right)$; rerata(SD) & $13,9(1,6)$ & $14,8(1,9)$ & 0,018 & $14,8(2,1)$ & $16,2(2,7)$ & 0,001 \\
$\begin{array}{l}\text { Kadar protein serum total } \\
(\mathrm{mg} / \mathrm{dl}) \text {; rerata (SD) }\end{array}$ & $3,82(0,52)$ & $6,19(0,76)$ & 0,001 & $4,12(0,82)$ & $6,16(0,67)$ & 0,001 \\
$\begin{array}{l}\text { Kadar albumin serum total } \\
(\mathrm{mg} / \mathrm{dl}) \text {; rerata (SD) }\end{array}$ & $1,39(0,30)$ & $3,43(0,43)$ & 0,001 & $1,75(0,59)$ & $3,21(0,59)$ & 0,001 \\
\hline
\end{tabular}


kadar protein dan albumin yang juga bermakna pada kelompok kontrol.

Pada Tabel 3 tampak perbandingan kadar protein total, albumin, globulin dan kadar kolesterol antara kelompok perlakuan dan kelompok kontrol pada awal dan akhir penelitian. Pada kedua kelompok tidak didapatkan perbedaan yang bermakna. Pada kelompok perlakuan yang mendapatkan tepung ikan gabus didapatkan selisih kenaikan (D) albumin lebih tinggi secara bermakna $(2,04 \pm 1,47 \mathrm{~g} / \mathrm{dl})$ dibandingkan kelompok kontrol $(1,47 \pm 0,82 \mathrm{~g} / \mathrm{dl})$ dengan $\mathrm{p}=0,018$ (Gambar 1)

\section{Pembahasan}

Pada akhir penelitian didapatkan adanya kenaikan (selisih) kadar albumin yang bermakna pada kelompok perlakuan dibandingkan dengan kontrol, dengan rerata perubahan sebesar 2,04 1,47 g/dl pada kelompok

Tabel 3. Rerata perubahan data laboratorium pada kelompok perlakuan dan kontrol

\begin{tabular}{lccc}
\hline Variabel & $\begin{array}{c}\text { Kelompok } \\
\text { Perlakuan } \\
\mathbf{n}=\mathbf{1 8}\end{array}$ & $\begin{array}{c}\text { Kelompok } \\
\text { Kontrol } \\
\mathbf{n}=18\end{array}$ & $\mathbf{p}$ \\
\hline Kadar protein serum total (g/dl); rerata (SD) & & & \\
$\quad$ Awal & $3,82(0,52)$ & $4,12(0,82)$ & 0,218 \\
$\quad$ Akhir & $6,19(0,76)$ & $6,16(0,67)$ & 0,871 \\
Kadar albumin serum total (g/dl); rerata (SD) & & & \\
$\quad$ Awal & $1,39(0,30)$ & $1,75(0,59)$ & $0,031^{*}$ \\
$\quad$ Akhir & $3,43(0,43)$ & $3,21(0,59)$ & 0,216 \\
Selisih kenaikan kadar albumin (g/dl); rerata (SD) & $2,04(1,47)$ & $1,47(0,82)$ & $0,018^{\wedge}$ \\
Kadar globulin serum total (g/dl); rerata (SD) & & & \\
$\quad$ Awal & $2,44(0,51)$ & $2,37(0,69)$ & 0,743 \\
$\quad$ Akhir & $2,77(0,57)$ & $2,89(0,42)$ & 0,469 \\
Kadar kolesterol serum (mg/dl); rerata (SD) & & & \\
$\quad$ Awal & $479,1(175,1)$ & $464,3(166,0)$ & 0,796 \\
$\quad$ Akhir & $296,8(106,0)$ & $300,4(118,7)$ & 0,925 \\
\hline
\end{tabular}

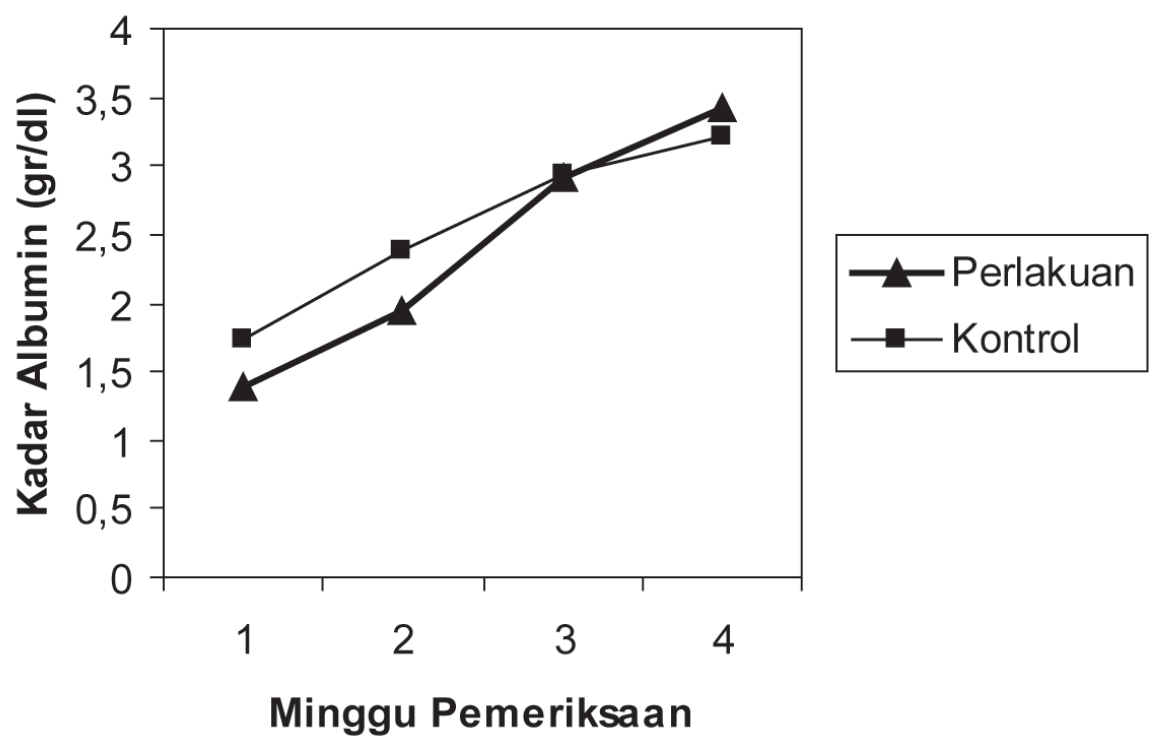

Gambar 1. Grafik kenaikan kadar albumin pada kedua kelompok 
perlakuan dibandingkan $1,75 \pm 0,59 \mathrm{~g} / \mathrm{dl}$ pada kelompok kontrol $(\mathrm{p}=0,018)$. Sedangkan pada pengamatan minggu sebelumnya kenaikan tersebut belum tampak. Hal ini mungkin terjadi karena masukan protein dari diet dapat menstimulasi sintesis albumin, dengan masa paruh albumin sekitar 20 hari. ${ }^{14,15}$

Penelitian Soemarko9 2002 di RS Saiful Anwar, Malang menggunakan ekstrak albumin dari ikan gabus segar (ekstrak $2 \mathrm{~kg} /$ hari) ditambah dengan putih telur selama 6 hari pada pasien pasca operasi dengan fistula enterokutan disertai hipoalbuminemia, mendapatkan peningkatan kadar albumin serum sebesar $0,934 \mathrm{~g} / \mathrm{dl}$ pada pemeriksaan sesudah dibandingkan dengan sebelum perlakuan.

Penelitian Maroni BJ $\mathrm{dkk}^{16}$ terhadap 5 pasien sindrom nefrotik dewasa yang mendapatkan diet rendah protein dan tinggi protein ternyata didapatkan keseimbangan nitrogen yang positif baik pada kelompok rendah maupun tinggi protein. Pada penelitian ini protein diberikan mulai dari $1,5 \mathrm{~g} / \mathrm{kgBB} /$ hari dan terbukti meningkatkan kadar protein dan albumin serum.

Pemberian suplementasi tepung ikan gabus selama 21 hari terbukti meningkatkan albumin serum secara bermakna. Ikan gabus adalah salah satu sumber protein hewani yang memiliki kandungan protein lebih tinggi dibandingkan beberapa ikan lain. Kandungan protein ikan gabus segar mencapai $25,2 \%$ dan albumin ikan gabus bisa mencapai $6,224 \mathrm{~g} / 100 \mathrm{~g}$ daging ikan gabus. Sebagai perbandingan protein ikan bandeng $(20,0 \%)$, ikan emas (16,0\%), ikan kakap (20,0\%), dan ikan sarden $(21,1 \%){ }^{8}$

Protein hewani memiliki kandungan asam amino esensial yang lebih tinggi dan memiliki digestibilitas yang lebih baik dibandingkan protein nabati karena tidak adanya kandungan serat. ${ }^{18}$ Protein efficacy ratio (PER) merupakan salah satu penilai kualitas protein yang mencakup nilai biologis dan nilai cerna. ${ }^{15}$ Formula tepung ikan gabus memiliki PER 2,81 lebih baik dibandingkan dengan PER kasein sebagai standar yaitu $2,5 .{ }^{13}$ Juga didapatkan kandungan asam amino rantai cabang yang tinggi pada ikan gabus, ${ }^{13}$ asam amino rantai cabang ini berperan dalam sintesis albumin di hepar. ${ }^{19-20}$ Salah satu pengukuran untuk menilai penggunaan protein diet adalah dengan keseimbangan nitrogen. ${ }^{15-16}$ Penelitian untuk mengetahui kinerja protein dari diet dengan menggunakan teknik $N$ labeled protein didapatkan bahwa nitrogen diet lebih berperan pada jalur anabolisme yaitu sintesis protein. ${ }^{21}$
Patogenesis sintesis protein pada sindrom nefrotik adalah multifaktorial dan dipengaruhi juga oleh kadar proteinuria. ${ }^{22}$ Pada penelitian ini kadar proteinuria diukur pada awal penelitian tetapi hubungan kenaikan kadar albumin dengan proteinuria tidak diteliti lebih lanjut.

Terjadinya kenaikan bermakna kadar serum albumin pada kelompok perlakuan mungkin disebabkan digestibilitas yang baik dan lebih tingginya kandungan asam amino esensial pada ikan gabus.

Keterbatasan penelitian ini adalah tidak dilakukan pengukuran keseimbangan nitrogen, ${ }^{15,18}$ dan digunakannya historical control karena jumlah kasus sindrom nefrotik di klinik kami tidak mencukupi.

\section{Kesimpulan}

Pemberian suplementasi tepung ikan gabus selama 21 hari pada pasien sindrom nefrotik kelainan minimal dapat meningkatkan kadar albumin serum. Ketersediaan ikan gabus yang cukup berlimpah dengan harga yang relatif murah menjadikan tepung ikan gabus salah satu pilihan yang sangat patut untuk diperhitungkan dalam tata laksana hipoalbuminemia pada kasus sindrom nefrotik.

\section{Daftar Pustaka}

1. Wirya W IGN. Sindrom Nefrotik. Dalam : Buku ajar nefrologi anak. Edisi kedua. Jakarta : Balai Penerbit FKUI ; 2002. h.381-426.

2. Orth S, Ritz E. The nephrotic syndrome. N Engl J Med 1998;338:1202-10.

3. Rodrigo R, Bravo I, Pino M. Proteinuria and albumin homeostasis in the nephrotic syndrome : effect of dietary protein intake. Nutr Rev 1996;54:337-47.

4. Mansy H, Goodship TH, Tapson JS, Hartley GH, Keavey P, Wilkinson R. Effect of high protein diet in patients with the nephrotic syndrome. Clin Sci 1989;77: 445-51.

5. Walser M, Hill S, Tomalis EA. Treatment of nephrotic adults with suplemented, very low protein diet. Am J Kidney Dis 1996;28: 354-64.

6. King FS, Burges A. Nutrition for developing Countries. Edisi kedua. London : Oxford University Press; 1996. h.23-30.

7. Kleinman RE, penyunting. Pediatric nutrition hand- 
book. Edisi keempat. Am Acad of Ped, 1998.

8. Santosa AH. Ekstraksi albumin ikan gabus (Ophiocephalus striatus). [skripsi]. Malang: Universitas Brawijaya, 2001.

9. Soemarko. Pemberian nutrisi enteral kaya albumin pada penderita fistula enterokutan. Maj Kedok Univ Braw $2002 ; 18: 32-5$.

10. Kosnadi L, Widajat RR. Sindrom Nefrotik. Dalam : Hartantyo I, Susanto R, Tamam M,Kosim MS, Irawan PW, Wastoro D, Sudigbia I, penyunting. Pedoman pelayanan medik anak. Edisi kedua. Semarang : Bagian IKA FK Undip/ SMF Kesehatan Anak RSUP Dr. Kariadi;1997. h.239-45.

11. Muchtar A. Beberapa aspek uji klinis (clinical trial). Dalam : Tjokronegoro A, Sudarsono S, penyunting. Metodologi penelitian bidang kedokteran.Edisi pertama.Jakarta : Balai Penerbit FKUI;2001.h.58-75.

12. Madyono B, Moeslichan Mz, Budiman I, Purwanto SH. Perkiraan besar sampel. Dalam : Sastroasmoro S, Ismael S, penyunting. Dasar - dasar metodologi klinis. Jakarta : Bina Rupa Aksara;1995. h.187-211.

13. Mien Karmini. Komposisi zat gizi makanan Indonesia. Bogor : P3Gizi Depkes Indonesia;2001.

14. Caso G. Albumin synthesis is diminished in men consuming a predominantly vegetarian diet. J Nutr 2000;130:528-33.
15. Gropper S, Smith JL, Groff JL, penyunting Advanced nutrition and human metabolism. Edisi ke-empat. Belmont: Thomson Wadsworth;2005. h.172-239.

16. Maroni BJ, Staffeld C, Young VR, Manatunga A, Tom K. Mechanisms permitting nephrotic patients to achieve nitrogen equilibrium with a protein restricted diet. Journal of Clinical Investigation 1997;99:2479-87

17. Protein metabolism. Dietary references intakes for energy, carbohydrates, fiber, fat, protein and amino acid (macronutrients) .2002. Didapat dari : URL:http:// www.nap.edul openbook/0309085373/html/485.html

18. Lee RD, Nieman DC. Nutritional assessment. Edisi ketiga. New York : McGraw-Hill;2003. h.303-37.

19. Stoll B, Burrin DG, Henry J, Yu H, Jahoor F, Reeds PJ. Dietary amino acids are the preferential source of hepatic protein synthesis in piglets. J Nutr 1998; 128:1517-24

20. Tessari P, Barazzoni R, Kiwanuka E. Impairment of albumin synthesis and whole body postprandial protein synthesis in compensated liver chirrosis. Am J Physiol Endocrinol Metab 2002;282:E304-11

21. Tome D, Bos C. Dietary protein and nitrogen utilization. J Nutr 2000;130 Suppl:S1868-73

22. Zanetti M. Plasma protein synthesis in patients with low-grade nephrotic proteinuria. AJP-Endo 2001; 280:591-7 